DOI 10.31558/2519-2949.2018.1.22

УДК 327.7:061.1ЕС

Корнійчук Л. В., Національний університет «Острозька академія»

\title{
ПРОБЛЕМИ РЕФОРМУВАННЯ ЄВРОПЕЙСЬКОГО СОЮЗУ НА СУЧАСНОМУ ЕТАПІ
}

У статті розглядаються ключові аспекти реформування Свропейського Союзу на сучасному етапі. На сьогодні Євросоюз знаходиться в процесі глибоких трансформаиійних перетворень, тому важливо з'ясувати їхню природу та можливі наслідки. Зроблено спробу показати взаємозв'язок внутрішьо- та зовнішньополітичних проблем СС із вибором майбутнього шлляху європейської інтеграиї̈ в напрямку розширення чи поглиблення. Охарактеризовано основні сиенарії майбутнього розвитку ЄС, а також пропозииії Президента Франції Еммануеля Макрона по реформуванню Співтовариства. Зокрема, окреслено пріоритетні напрямки майбутніх реформ такі як: безпекова та мігращійна політика, спільне фінансування інноваційних проектів, а також формування спільного бюджету для координаиії інвестииійної діяльності та стабілізаиії у випадку майбутніх економічних криз. Увагу приділено особливостям інтеграційних заходів СС у сфері безпеки та оборони, яка зазнала змін після Вrехіt та еволюиії політики США щодо свойх європейських партнерів.

Особливий акиент у публікації зроблено на здійснення практичного кроку у реформах створення нового оборонного та безпекового проекту PESCO (Постійної структурованої співпрачі у сфері оборони краӥн-членів (С), щцо покликаний зробити європейську оборону більш ефективною $i$ посилити оперативну співпрацю між державами. Головною ідеєю співробітництва у такому форматі є підвищення ефективності завдяки спільному виконанню того, щзо кожна з країн до иього робила самостійно. Водночас, важливо, що участь у проектах кожної краӥни є добровільною. Оскільки сьогодні Свропейський Союз розглядається не лише як потужсне економічне об'єднання, а й як досить потужний гравецьь на міжнародній арені, який впливає на підтримку стабільного міжнародного порядку, то у статті представлено аналіз особливостей трансформацій, що $\epsilon$ необхідними для подальшої життєздатності Співтовариства.

Ключові слова: Свропейський Союз, реформи, системна криза, глобальні виклики, безпека.

Зважаючи на тенденції останніх років, у розвитку ЄС почала проявлятися системна криза, на яку вплинуло низка масштабних проблем, зокрема світова фінансова та міграційна кризи, терористична загроза, безпекові виклики у Східноєвропейському регіоні у зв'язку 3 агресією Російської Федерації, проблеми трансатлантичної співпраці в контексті діяльності адміністрації США після президентських виборів 2016 р., а також наростання протиріч у самому Співтоваристві у зв'язку із загостренням сепаратистських рухів, Brexit тощо. Гальмування інституційних процесів та неможливість подальшого поглиблення інтеграції змушує провідні держави $€ С$ шукати можливості подолання кризових явищ та розробляти нову глобальну стратегію розвитку, яка б дозволяла ефективно реагувати на виклики, що постійно виникають у глобалізованому світі.

Процес реформування та розширення ЄС через включення до Спільноти держав ЦентральноСхідної та Південної Європи 3 одногу боку сприяв зміцненню міжнародної ролі ЄС як репрезентанта 28 держав, а 3 іншого - все ж не вдалося подолати ні диспропорцій у господарському розвитку держав-учасниць, ні різниці у зовнішньополітичних інтересах, що звичайно теж вплинуло на початок проявів певних кризових явищ у функціонуванні. Водночас, $Є С$ почав відігравати роль глобального гравця на міжнародній арені і ця позиція вимагає від нього подальшого посилення участі у розв'язанні проблем світової політики, а відтак набуває ще більшого значення потреба досягнення єдиної позиції усіма членами СС. Очевидно, що подолання кризових явищ вимагає проведення системних реформ, що дозволять Співтовариству не лише втримати, а й посилити свої позиції на міжнародній арені.

Сучасні дослідження, що присвячені вивченню проблеми реформування ЄС мають фрагментарний характер, що зумовлює необхідність аналізу викликів, що постають перед ЄС і шляхів реагування на них. Водночас, не можна не згадати про цінні наукові розвідки, що проливають світло на дилеми модернізації окремих політик $Є С$ таких українських дослідників як 
В. Манжола, В. Копійка, Т. Сидорук, В. Завадський, С. Пациківський та ін., а також зарубіжних науковців - В. Войке, М. Еммерсон, Д. Бойлер, К. Жукровська, Р. Зємба, М. Ласонь, Я. Чапутович та ін. Водночас, питання характеристики основних проектів реформ ЄС та можливостей їхнього впровадження потребує детальнішої уваги.

Метою представленої статті є аналіз основних підходів до процесу реформування Євросоюзу та алгоритмів подолання глобальних викликів сучасності.

Слід підкреслити, що 1 березня 2017 р. Сврокомісія презентувала Білу книгу про майбутнє Європи до 2025 р., а пізніше, 25 березня під час саміту ЄС з нагоди 60-річчя підписання Римських угод, Президент Європейської комісії Жан-Клод Юнкер озвучив п'ять сценаріїв можливого розвитку Співтовариства [12]. Перший сценарій передбачає втілення поточної програми реформ, що була презентована Єврокомісією ще у 2014 р. Фактично це означає нічого не змінювати, а це своєю чергою може призвести до ще більшого наростання протиріч між державами-членами, ускладнить процедуру ухвалення рішень з важливих питань, а про ефективність їх виконання в такому випадку говорити буде ще складніше. Другий сценарій - «залишити лише єдиний ринок» - означає згортання окремих частин політичної інтеграції між учасниками $\mathrm{CC}$ при збереженні єдиного європейського ринку товарів і послуг. У такому випадку держави вирішуватимуть протиріччя в двосторонньому порядку. Третій сценарій «Європа декількох швидкостей» передбачає, що за бажанням учасників відбувається поглиблена інтеграція в певних сферах, а інші члени теж, коли захочуть можуть долучатися до відповідних ініціатив. Однак, у такому випадку окремі держави побоюються, що може сформуватися група країн, що матимуть переважаючий вплив на прийняття рішень, натомість найменш залучені до інтеграції держави втратять можливості впливати на цей процес. Четвертий сценарій - «робити менше, але ефективніше» - покликаний збільшити результативність дій ЄС в окремих галузях завдяки направленню на них основних ресурсів. У документі передбачається, що це, охоплюватиме такі галузі, як регіональний розвиток, охорона здоров'я, частини спільної трудової та соціальної політики, що безпосередньо не пов'язані 3 функціонуванням єдиного ринку [6]. Нарешті п’ятий сценарій - «робити більше, але разом» фактично означає розвиток ідеї Сполучених Штатів Європи, тобто поглиблення подальшої інтеграції між учасниками в усіх галузях і передача повноважень на загально-організаційний рівень, утворюючи таким чином федерацію. Натомість у Римській декларації від 26 березня 2017 р. визначено загальні пріоритети розвитку СС такі як: безпека, економічний розвиток, соціальна політика та спільна зовнішня політика [10] без зазначення шляхів реалізації цих напрямів політики.

Зауважимо, що лідер німецьких соціал-демократів Мартін Шульц 7 грудня 2017 p. на партійному з'їзді в Берліні заявив, що для збереження європейської єдності ЄС необхідно до 2025 року перетворити в Сполучені Штати Європи, які укладуть спільний конституційний договір. Договір буде представлений державам-членам $€ \mathrm{C}$ для ратифікації, i ті, хто відмовляться від нього, на його думку, автоматично повинні залишити блок. М. Шульц переконаний, що лише посилений $\mathrm{CC}$ може діяти на противагу правим націоналістам, які останнім часом досягли успіхів у Німеччині, Австрії, Данії, Фінляндії, Франції та Нідерландах [7]. Однак, ця ідея одразу ж зустріла критику від представників блоку Ангели Меркель. Зокрема, один із керівників блоку ХДС/ХСС консерватор Фолькер Каудер заявив, що пропозиція Шульца «становить загрозу для ЄС i громадянського схвалення Свропи» [2]. Правляча більшість німецького політикуму не просто відкидає подібні ідеї, а й вважає іх такими, що перекреслюють значну роботу, проведену десятиліттями по створенню і реформуванню ЄС до сучасного вигляду. Враховуючи той факт, що ідея передачі суверенітету державами-членами у Брюссель, наврядчи зустріне підтримку в громадськості, то плани по утворенню Сполучених Штатів Свропи виглядають не досить реалістично.

Загалом же, як бачимо, представлені проекти по реформуванню ЄС мають і найбільш песимістичний сценарій (другий), і найбільш оптимістичний (п'ятий), однак жоден із них не дозволяє повною мірою подолати всі труднощі, що існують всередині Спільноти, тому ймовірно реалізовано буде взагалі інший, комбінований на основі задекларованих на саміті пропозицій, сценарій.

Питання пошуку нової моделі співпраці в рамках СС до 2025 р. ще 3 більш посиленою активністю почало обговорюватися після президентських виборів у Франції та парламентських виборів у ФРН. Зокрема, Президент Франції Еммануель Макрон 26 вересня 2017 р. під час виступу перед студентами паризького університету Сорбонна висловив пропозиції щодо масштабної реформи ЄС до 2024 р. Серед запропонованих змін чільне місце займає ідея посилення Єврозони і на його думку, країни Єврозони потребують спільного бюджету для фінансування спільних 
інвестицій та забезпечення стабільності в період економічних криз [3]. Важливими також $€$ фінансування та координація інноваційної діяльності і тому пропонується заснувати Агентство проривних інновацій, спільно фінансувати новаторські проекти, врегулювати оподаткування в цих сферах. Ухвалення спільного бюджету очевидно передбачатиме посаду міністра фінансів та парламентський нагляд на загальноєвропейському рівні. За задумом такий крок міг би допомогти значно скоротити безробіття, частка якого значно зросла останнім часом, і не означає, що йдеться про перенесення боргів одних держав на інші. Наповнення бюджету, згідно із пропозицією Е. Макрона, має відбуватися через впровадження єдиного податку на фінансові операції, через оподаткування великих інтернет-компаній, що повинні сплачувати податки в тих країнах, де отримують прибутки, а не там де зареєстровані. Зауважимо, що під час Всесвітнього економічного форуму у Давосі, що відбувся в січні 2018 р., Е. Макрон повторно представив своє бачення реформування $\mathrm{CC}$ і зокрема, ще раз підкреслив важливість створення нової посади - міністра ЄС 3 питань фінансів для посилення регулювання Єврозони. Оскільки спільний економічний простір ЄС інституційно незавершений, то це заклало відповідні диспропорції в економічному розвитку держав Сврозони, адже разом зібралися економіки різного типу. Запровадження єдиної фіскальної політики може стати значним кроком для подальшої поглибленої інтеграції.

Ще одним важливим аспектом є реформування безпекової сфери, зокрема лідером Франції була висловлена пропозиція створити спільні сили швидкого реагування та спільний оборонний бюджет, спільні підрозділи цивільної оборони, а також спільну безпекову доктрину. Оскільки одним із нагальних безпекових питань $€$ проблема нелегальної міграції, то Е. Макрон запропонував створити загальноєвропейське агентство з надання притулку, яке прискорить та уніфікує відповідні процедури, а також необхідним є поступове створення спільної прикордонної служби. Крім того, було запропоновано запровадити стандартні ідентифікаційні документи для всього ЄС, адже лише спільними зусиллями об'єднаної Свропи можна ефективно захистити зовнішні кордони та надавати притулок тим, хто цього потребує [3]. У списку запропонованих ініціатив також створення спільної служби захисту населення від наслідків природних катастроф та поглиблення співпраці європейських спецслужб, зокрема створення Європейських сил цивільної оборони (для боротьби зі стихійними лихами) та Європейської академії розвідки. Крім того, є також пропозиції щодо сприяння функціонуванню більш екологічно чистої промисловості через фіксацію цін на вугілля всередині ЄС та встановлення додаткового податку на експортоване вугілля.

Зауважимо, що раніше, 7 червня 2017 р. Сврокомісія представила аналітичну доповідь «Майбутнє європейської оборони», в якій охарактеризовано ключові тенденції та виклики у безпековій та оборонній сфері СС, а також викладено три сценарії подолання загроз та посилення оборонної спроможності держав ЄС до 2025 р. Серед можливостей майбутнього європейської оборони сценарії: «Співпраця в галузі безпеки і оборони», «Колективна безпека і оборона» та «Спільна оборона і безпека». Перший сценарій передбачав розвиток співпраці залежно від конкретного випадку та індивідуальний порядок контролю над оборонним потенціалом та закупівлями. Другий - об'єднання певних фінансових та операційних активів для зміцнення солідарності в питаннях оборони. У третьому випадку захист Європи стане відповідальністю ЄС та НАТО, співпраця яких матиме взаємодоповнюючий характер і реалізуватиметься ЄС через Європейський оборонний фонд [1]. Зрозуміло, що важливим кроком став перехід від обговорень проектів до конкретного ухвалення планів реалізації достатньо амбітних програм у безпековій та оборонній сферах, а також посилення СС своїх управлінських структур завдяки створенню військового штабу.

Враховуючи той факт, що безпекова ситуація в Європі за останні роки зазнала значних змін і держави $Є С$ виявилися оточені аж ніяк не «колом друзів», а також зрозуміли, що актуальною для них лишається небезпека зі сходу, а позиція Президента США Дональда Трампа щодо НАТО не забезпечує повною мірою гарантій безпеки європейцям, то у реформуванні оборонної сфери вже було зроблено певні практичні кроки. Так, Ж.-К. Юнкер у вересні 2017 р. під час виступу в Свропарламенті заявив про створення до 2025 р. Свропейського оборонного союзу, що існуватиме паралельно і в партнерстві з НАТО. Це зможе дозволити для СС самостійно діяти в операціях за кордоном для стабілізації сусіднього простору і посилення своєї ролі як гаранта безпеки. Крім того, резолюція Європарламенту пропонувала заснувати Головне управління з питань оборони, яке б на рівні ЄС відповідало за внутрішні аспекти політики оборони і безпеки, а також створити Свропейський розвідувальний відділ [4].

Рада СС 11 грудня 2017 р. ухвалила рішення про старт програми Permanent Structured Cooperation (PESCO) - Постійної структурованої співпраці у сфері оборони країн-членів ЄС. 
Створення PESCO передбачала ще Лісабонська угода 2009 року і визначала можливість того, що низка країн-членів ЄС тісніше співпрацюватимуть у сфері безпеки та оборони. Ця постійна структура оборонного співробітництва дозволить бажаючим і здатним державам-членам розвивати спільні оборонні можливості, інвестувати в спільні проекти. Водночас, у ЄС підкреслюють, що PESCO не є альтернативою НАТО, який і надалі буде наріжним каменем колективної оборони для своїх членів, а є лише рамками для реалізації державами-членами ЄС спільних проектів. Названа ініціатива має сприяти підсиленню обороноздатності Євросоюзу і дозволити спільно протистояти військовим загрозам. Участь у програмі є добровільною для держав-учасниць ЄС, відтак до нового об'єднання не приєдналися Данія, Мальта та Великобританія. Програма передбачає підвищення військової мобільності країн $\mathrm{CC}$, створення єдиного центру реагування на кризи та мережі логістичних центрів для підтримки операцій. Держави-члени, що беруть участь в PESCO, також прийняли заяву одночасно 3 прийняттям рішення про створення ініціативи, в якій вітається ухвалення політичної угоди щодо здійснення 17 проектів у майбутньому, зокрема у сфері розвитку можливостей та в оперативному вимірі, починаючи від створення Європейського медичного командування, Центру компетенції навчальної місії $Є C$, груп швидкого реагування та взаємодопомоги, допомоги в галузі кібербезпеки та у ліквідації наслідків стихійних лих, вдосконалення морського нагляду тощо [9]. Ефективність ініціативи i буде вимірюватися реалізацією задекларованих проектів. Окрім того, держави-учасниці ініціативи взяли на себе зобов'язання по оптимізації оборонних витрат через спільні інвестиції заради більшої ефективності безпекової політики, адже їхні оборонні витрати і потенціал у сфері безпеки не відповідають вимогам сучасності.

Водночас, присутній ризик того, що у майбутньому у держав можуть виникнути розбіжності, наприклад при укладанні контрактів на певні оборонні замовлення. Також вже помітні розбіжності серед членів ЄС щодо питання формування довгострокового бюджету на 2021-2027 pp., адже Великобританія вже вийде зі Співтовариства і бюджет за різними оцінками недораховуватиметься щорічно близько 12 млрд. євро, а потребуватиме додаткових витрат на оборону та безпеку. Невдоволення викликає також ідея прив'язати виплати з фондів ЄС до дотримання верховенства права та міграційної політики. Не всі держави готові збільшити свої внески в бюджет, а тому фінансове питання найближчим часом стане серйозним випробуванням на міцність для Спільноти i своєрідним тестом на здатність не лише ухвалювати домовленості, а й втілювати їх у життя, особливо коли це стосується стратегічно важливих сфер.

Вагомим напрямом реформування СС є також скорочення бюрократії, а тому серед пропозицій французького лідера - скорочення кількості членів Сврокомісії в перспективі до п'ятнадцяти осіб (наразі кожна країна делегує свого єврокомісара). Внаслідок таких перетворень Європа стане «простішою, транспарентнішою та менш забюрократизованою» [3]. Однак, очевидно, що ці пропозиції мають бути підтримані Спільнотою і передусім, Е. Макрон закликав ФРН підтримати реформи та поставити за мету до 2024 р. повністю інтегрувати ринки обох держав. Власне, незважаючи на певні побоювання щодо того, що можливо спільний європейський бюджет в майбутньому може призвести до сплати Німеччиною мільйонів євро за інші країни, все ж А. Меркель заявила, що запропоновані французьким президентом реформи сприятимуть розвитку Євросоюзу та посилять співробітництво між двома країнами. Також, за ії словами, ці реформи можуть сформувати основу для інтенсивного франко-німецького співробітництва [5]. Така позиція лідерів двох провідних держав в СС певною мірою зумовлена також тим, що до 2020 р. відбудуться вибори до Європарламенту та зміна керівництва Єврокомісії, а відтак спільна позиція та спільний план дій і конкретні кроки по його реалізації повинні продемонструвати європейській спільноті, що ЄС здатен подолати кризу і поглиблення євроінтеграції є надзвичайно важливим для подолання не лише внутрішніх, а й зовнішніх загроз. Франція та Німеччина стають рушійними силами реформ у $€ \mathrm{C}$, а відтак увага громадськості прикута до переговорів їх лідерів та очікує погодженого плану щодо реформування Співтовариства.

Не можна не звернути увагу і на акценті важливості створення нового партнерства з Африкою, яке буде грунтуватися на сферах освіти, охороні здоров'я та транспортуванні енергії. Це підкреслює, що цей регіон все ж у майбутньому визначатиметься як більш пріоритетний для $Є \mathrm{C}$, ніж, скажімо, регіон охоплений ініціативою «Східне партнерство». У такому випадку для України це не дуже позитивний сигнал, адже фактично відмова від політики розширення і незацікавленість у східному вимірі політики сусідства не відповідає українським євроінтеграційним інтересам.

Отже, на сьогодні достатньо виопуклилася проблема реалізації системних реформ у ЄС, адже очевидною стала вразливість Співтовариства перед сучасними викликами. Зокрема, криза Єврозони, 
вихід із ЄС Великобританії, міграційна криза, зростання популярності в державах-членах крайньоправих політичних сил, російська агресивна політика, позиція Д. Трампа щодо безпекового становища європейських країн - все це стимулювало винесення на порядок денний ЄС проведення реформування, яке назрівало достатньо давно. Запропоновані варіанти реформ мають на меті зміцнити Євросоюз, сприяти ефективному реагуванню на внутрішньополітичні та зовнішньополітичні виклики. Оскільки найбільш гостро постали економічні та безпекові проблеми, то й найактивніші обговорення та перші практичні кроки в СС здійснюються по реформуванню саме цих сфер діяльності. Йдеться, про вдосконалення координації економічної політики, приділення більшої уваги зайнятості населення та соціальним проблемам, впровадження спільної фіскальної політики, а також нового оборонного та безпекового проекту PESCO, що покликаний зробити європейську оборону більш ефективною $\mathrm{i}$ досягати більшого обсягу виробництва, забезпечуючи посилену координацію та співпрацю у сфері інвестицій, розвитку спроможності та оперативної готовності. Подальше втілення досить амбітного плану реформ, запропонованого французьким президентом значною мірою залежатиме від підтримки його іншими учасниками Співтовариства, а також від того переважать національні інтереси чи все ж загальні цінності, бо лише у другому випадку СС вдасться вистояти перед обличчям найсерйознішої кризи із часів заснування та стати сильнішим і впливовішим міжнародним гравцем. Перспективним для подальших розвідок вважаємо подальше вивчення реформ окремих політик ЄС, прогнозування вибору моделі подальшої інтеграції, а також аналіз можливих нових викликів у коротко-, середньо- та довгостроковій перспективі, що можуть виникнути перед Свросоюзом та можливих варіантів реагування на такі загрози.

\section{Бібліографічний список:}

1. Александров О.С. Розвиток спільної зовнішньої та безпекової політики Свропейського Союзу. Перспективи для України [Електронний ресурс] / О.С. Александров // Національний інститут стратегічних досліджень. - Режим доступу: http://www.niss.gov.ua/content/articles/files/Aleksandrov-91492.pdf

2. Консерватори Меркель відкинули ідею Шульца про «Сполучені Штати Свропи» [Електронний pecypc] // Європейська правда. - Режим доступу: http://www.eurointegration.com.ua/news/2017/12/11/7074884/

3. Макрон запропонував масштабну реформу Євросоюзу [Електронний ресурс] // DW Made of minds. Режим доступу: http://www.dw.com/uk/макрон-запропонував-масштабну-реформу-євросоюзу/a-40695848

4. Марутян P. PESCO - новий європейський оборонний союз: можливості для України [Електронний pecypc] / Р. Марутян // Режим доступу: http://matrix-info.com/2018/01/13/pesco-novyj-yevropejskyj-oboronnyjsoyuz-mozhlyvosti-dlya-ukrayiny/

5. Меркель похвалила запропонований Макроном план реформування $\mathrm{CC} \mathrm{[Електронний} \mathrm{ресурс]}$ // DW Made of minds. - Режим доступу: http://www.dw.com/uk/меркель-похвалила-запропонований-макрономплан-реформування-єс/а-40735396

6. Нагорняк I. Біла книга щодо майбутнього СС. Чи є в ньому місце для України? [Електронний ресурс] / I. Нагорняк // СД Платформа. - Режим доступу: https://sdplatform.org.ua/blogs/50/bila-kniga-sodo-maibutnogoes-ci-e-v-nomu-misce-dla-ukraini

7. Шульц пропонує створити «Сполучені Штати Свропи» до 2025 року [Електронний ресурс] // Свропейська правда. - Режим доступу: http://www.eurointegration.com.ua/news/2017/12/7/7074786/

8. Czaputowicz J. Globalna strategia UE - koniec Unii Europejskiej jako potęgi normatywnej? / J. Czaputowicz // Przegląd Europejski. - Warszawa: Instytut Europeistyki. - № 4 (42), 2016. - S. 25-36.

9. Defence cooperation: Council establishes Permanent Structured Cooperation (PESCO), with 25 member states participating [Електронний ресурс] // European Council. Council of the European Union. - Режим доступу: http://www.consilium.europa.eu/en/press/press-releases/2017/12/11/defence-cooperation-pesco-25-member-statesparticipating/

10. White Paper on the Future of Europe. Reflections and Scenarios for EU27 by 2025, EC COM (2017) 2025 of 1 March 2017 [Електронний ресурс]. - Режим доступу: https:/ec.europa.eu/commission/sites/betapolitical/files/ white_paper_on_the_future_of_europe_en.pdf

11. Zięba R. Próby ożywienia polityki bezpieczeństwa i obrony Unii Europejskiej / R. Zięba // Krakowskie Studia Międzynarodowe. Część 1: Zagrożenia, wyzwania i przyszłość polityki bezpieczeństwa Unii Europejskiej w dobie kryzysu / Redakcja Erhard Cziomer. - Kraków: Krakowska Akademia im. Andrzeja Frycza Modrzewskiego, 2017. - S. 35-52.

12. Żukrowska K. Rozwój Unii Europejskiej do 2020 roku a nowe wyzwania globalizacji i konkurencji międzynarodowej z uwzględnieniem roli, miejsca i interesów Polski / K. Żukrowska // Krakowskie Studia Międzynarodowe. Część 1: Zagrożenia, wyzwania i przyszłość polityki bezpieczeństwa Unii Europejskiej w dobie kryzysu / Redakcja Erhard Cziomer. - Kraków: Krakowska Akademia im. Andrzeja Frycza Modrzewskiego, 2017. S. 17-33. 


\section{Korniichuk L. V. The European Union problems of reforming at the present stage}

The article considers the key aspects of the European Union reforming at the present stage. Currently the European Union is in the process of deep transformational reformation, that's why it is important to find out their nature and possible consequences. An attempt is made to show the interconnection of internal and foreign poilicy problems of EU with the choice of the future path of European integration in the direction of expansion or deepening. The main scenarios for the future development of the EU are described, as well as the propositions of the President of France Emmanuel Macron to reform the Community. The priority directions of future reforms are particularly estimated, such as: security and migration policy, joint financing of innovation projects, and also the formation of an overall budget for coordination of investment activity and stabilization in case of future economic crises. It was paid attention to the peculiarities of the EU integration in the security and defense fields and there changes towards its European partners since Brexit and the evolution of the US policy.

A special emphasis in the publication is made on realization of a practical step in reforms - creation of a new defense and security project PESCO, which is intended to make European defense more effective and to strengthen operational cooperation between countries. The main idea of cooperation in this form is to increase efficiency through the joint implementation of what every country has done by its own before. At the same time it is important that participation in the projects of each country is voluntary. Currently the $E U$ is considered not only as a powerful economic association, but also as a very powerful player in the international arena, which influences on the maintenance of continual international order. That's why the article presents an analysis of the peculiarities of transformations that are necessary for the further viability of the EU.

Key words: the European Union, reforms, systemic crisis, global challenges, security. 